\title{
Profil kandidiasis vulvovaginalis di Poliklinik Kulit dan Kelamin RSUP Prof. Dr. R. D. Kandou Manado periode Januari - Desember 2013
}

\author{
${ }^{1}$ Novita L. Tasik \\ ${ }^{2}$ Grace M. Kapantow \\ ${ }^{2}$ Renate T. Kandou
}

\author{
${ }^{1}$ Kandidat Skripsi Fakultas Kedokteran Universitas Sam Ratulangi Manado \\ ${ }^{2}$ Bagian/SMF Ilmu Kesehatan Kulit dan Kelamin RSUP Prof. Dr. R. D. Kandou Manado \\ Email: novita_limbutasik@yahoo.com
}

\begin{abstract}
Vulvovaginalis candidiasis (VVC) is a disease of female reproductive organs with the site of infection at the vulva and vagina mucosa characterized by vaginal discharge and itching due to the uncontrolled growth of the fungus Candida albicans. This study aimed to obtain the profile of vulvovaginalis candidiasis cases at Prof. Dr. R. D. Kandou Hospiptal Manado from January to December 2013. This was a retrospective descriptive study using the medical record. The results showed that of $29 \mathrm{VVC}$ cases $(0.70 \%)$, the largest age groups were $15-24$ and 25-44 years (41.4\%). Housewives and students were the most found jobs (20.7\%). The discharge accompanied by itching was found in $34.5 \%$ of cases. The use of douching and pregnancy were predisposing factors (13.8\%). Gram examinations resulted in spores, budding cell, and pseudohyphae were found in $62.1 \%$ of cases. Patients who was infected by VVC for the first time were $82.8 \%$. The most frequent type of therapy was combination therapy $(48.3 \%)$.
\end{abstract}

Keywords: vulvovaginalis candidiasis

\begin{abstract}
Abstrak: Kandidiasis vulvovaginalis (KVV) merupakan suatu penyakit organ reproduksi pada wanita dimana terjadi infeksi pada mukosa vulva dan vagina ditandai dengan adanya keputihan dan gatal dikarenakan pertumbuhan tidak terkendali dari jamur Candida albicans. Penelitian ini bertujuan untuk mengetahui profil pasien kandidiasis vulvovaginalis di RSUP Prof. Dr. R. D. Kandou Manado periode Januari - Desember 2013. Penelitian ini bersifat deskriptif retrospektif dengan mengevaluasi catatan rekam medik pasien. Hasil penelitian menunjukkan terdapat 29 kasus KVV. Kelompok umur terbanyak 15-24 dan 25-44 tahun $(41,4 \%)$; pekerjaan terbanyak ialah ibu rumah tangga dan pelajar (20,7\%); keputihan disertai gatal (34,5\%); faktor predisposisi terbanyak yaitu penggunaan douching dan kehamilan (13.8\%). Pemeriksaan Gram ditemukan spora, buddingcell dan pseudohifa ditemukan pada 62,1\% kasus. Pasien yang baru pertama kali terinfeksi KVV sebanyak 82,8\%. Jenis terapi terbanyak yang diberikan yaitu terapi kombinasi sebanyak 48,3\%).
\end{abstract}

Kata kunci: kandidiasis vulvovaginalis

Kandidiasis vulvovaginalis (KVV) merupakan suatu penyakit organ reproduksi pada wanita dimana terjadinya infeksi pada mukosa vulva dan vagina ditandai dengan adanya keputihan dan gatal dikarenakan pertumbuhan tidak terkendali dari jamur Candida albicans. ${ }^{1,2}$ Penyebab terbanyak KVV ialah spesies Candida albicans (80-
90\%), ${ }^{3,4}$ disusul oleh Candida glabrata (29,79\%), Candida tropicalis (3,19\%), Candida krusei (2,13\%), dan Candida parapsilosis $(1,06 \%)^{5}$

Infeksi Candida sendiri merupakan penyebab terbanyak keputihan pada wanita yang berwarna putih kekuningan, berbau, rasa terbakar, dan gatal yang hebat pada 
organ vital. ${ }^{6}$ Jamur Candida pada manusia merupakan jamur flora normal yang hidup pada organ reproduksi, namun dapat menjadi patogen bila terdapat faktor pencetus yang menimbulkan perubahan pada daerah vagina. ${ }^{7}$ Kandidiasis vulvovaginalis dikaitkan dengan banyak faktor pencetus seperti penggunaan pembersih kewanitaan, penggunaan antibiotik, kurangnya higiene kewanitaan. Selain itu, KVV juga bisa menyerang para wanita dengan adanya riwayat penyakit diabetes dan terjadi juga pada kehamilan. ${ }^{6,8,9}$

Jamur Candida albicans dapat bertumbuh pada daerah vagina dalam kondisi yang kurang bersih dan lembab, sehingga wanita yang berpengetahuan kurang dalam hal pentingnya menjaga kebersihan organ reproduksi akan memengaruhi perilaku mereka dalam menjaga kebersihan organ reproduksi. Hal ini merupakan salah satu faktor predisposisi yang menyebabkan timbulnya KVV karena kebersihan organ reproduksi yang buruk dapat menyebabkan perubahan lingkungan pada vagina sehingga flora normal yang ada akan bertumbuh menjadi patogen. ${ }^{7}$

Kandidiasis vulvovaginalis merupakan penyebab terbanyak kedua penyakit yang menyerang wanita di Eropa dan Amerika Serikat. ${ }^{8}$ Di India pada tahun 2013, kandidiasis vulvovaginalis (53,3\%) menyerang kelompok wanita usia reproduksi antara 21-30 tahun dengan penyebab terbanyak yaitu Candida albicans (86\%). ${ }^{9}$

Penelitian yang dilakukan di Divisi IMS Unit Rawat Jalan Kesehatan Kulit dan Kelamin RSUD Dr. Soetomo Surabaya pada tahun 2011 dilaporkan bahwa KVV (65,4\%) merupakan diagnosis terbanyak dengan keluhan utama berupa adanya duh tubuh vagina dan rasa gatal $(52,6 \%)$ pada penderita. $^{10}$ Dilaporkan dari sebuah penelitian di Puskesmas Merak Jawa Barat bahwa sebanyak 58\% wanita hamil menderita infeksi saluran reproduksi dan sekitar 9,1\% diantaranya adalah kandidiasis vulvovaginalis. ${ }^{11}$

Insidensi KVV di Poliklinik Kulit dan
Kelamin RSUP Prof. Dr. R. D. Kandou pada tahun 2012 yaitu sebanyak 47 kasus (1,17\%) dari 4.023 pasien yang datang berkunjung. Dari hasil data diatas, peneliti tertarik untuk mengetahui Profil Pasien Kandidiasis Vulvovagialis di Poliklinik Kulit dan Kelamin RSUP Prof. Dr. R. D. Kandou Manado Periode Januari Desember 2013.

\section{METODE PENELITIAN}

Penelitian ini bersifat deskriptif retrospektif dengan mengumpulkan dan mengevaluasi data sekunder dari catatan rekam medik pasien kandidiasis vulvovaginalis di Poliklinik Kulit dan Kelamin RSUP Prof. Dr. R. D. Kandou Manado periode Januari - Desember 2013. Sampel penelitian yaitu semua pasien dengan diagnosis kandidiasis vulvovaginalis yang datang berobat. Variabel penelitian terdiri atas umur, pekerjaan, riwayat keluhan, faktor predisposisi, pemeriksaan laboratorium, riwayat penyakit sebelumnya, dan terapi.

\section{HASIL PENELITIAN}

Berdasarkan penelitian retrospektif di Poliklinik Kulit dan Kelamin RSUP Prof. Dr. R. D. Kandou Manado periode JanuariDesember 2013, diperoleh data sebanyak 29 kasus yang didiagnosis KVV dari 47 kasus KVV yang ada di Devisi IMS dengan total keseluruhan terdapat 4.099 pasien yang berkunjung ke Poliklinik Kulit dan Kelamin.

Distribusi kasus kandidiasis vulvovaginalis berdasarkan jumlah kasus tahun 2013 sebanyak 29 kasus (0,70\%) dari 4.099 kasus di Poliklinik Kulit dan Kelamin RSUP Prof. Dr. R. D. Kandou Manado pada tahun 2013 (Tabel 1).

Distribusi kasus kandidiasis vulvovaginalis berdasarkan umur pasien saat memeriksakan diri di Poliklinik Kulit \& Kelamin RSUP Prof. Dr. R. D. Kandou periode Januari-Desember 2013, didapatkan jumlah terbanyak pada golongan umur 15-24 tahun dan 25-44 tahun masingmasing sebanyak 12 kasus (41,4\%) diikuti golongan umur 45-65 tahun sebanyak 4 
kasus (13,8\%) (Tabel 2).

Tabel 1. Distribusi Kasus Kandidiasis Vulvovaginalis Berdasarkan Jumlah Kasus di RSUP Prof. Dr. R. D. Kandou Manado Tahun 2013

\begin{tabular}{cccc}
\hline Tahun & $\begin{array}{c}\text { Jumlah Seluruh } \\
\text { Kasus di } \\
\text { Poliklinik Kulit } \\
\text { \& Kelamin }\end{array}$ & $\begin{array}{c}\text { Jumlah } \\
\text { Kasus } \\
\text { Kandidiasis } \\
\text { Vulvovaginal } \\
\text { is }\end{array}$ & $\%$ \\
\hline 2013 & 4.099 & 29 & 0,70 \\
\hline
\end{tabular}

Tabel 2. Distribusi Kasus Kandidiasis Vulvovaginalis Berdasarkan Umur Pasien di RSUP Prof. Dr. R. D. Kandou Manado Tahun 2013

\begin{tabular}{ccc}
\hline Umur (tahun) & Jumlah Kasus & $(\%)$ \\
\hline$<1$ & 0 & 0 \\
$1-4$ & 0 & 0 \\
$5-14$ & 1 & 3,4 \\
$15-24$ & 12 & 41,4 \\
$25-44$ & 12 & 41,4 \\
$45-65$ & 4 & 13,8 \\
$>65$ & 0 & 0 \\
Total & 29 & 100,0 \\
\hline
\end{tabular}

Distribusi kasus kandidiasis vulvovaginalis berdasarkan pekerjaan pasien didapatkan jumlah terbanyak yaitu sebagai ibu rumah tangga dan pelajar masingmasing sebanyak 6 kasus (20,7\%), diikuti sebagai profesi PNS sebanyak 5 kasus $(17,3 \%)$, dan pekerja swasta sebanyak 4 kasus (13,8\%) (Tabel 3).

Tabel 3. Distribusi Kasus Kandidiasis Vulvovaginalis Berdasarkan Pekerjaan Pasien di RSUP Prof. Dr. R. D. Kandou Tahun 2013

\begin{tabular}{lcc}
\hline \multicolumn{1}{c}{ Pekerjaan } & Jumlah Kasus & $(\%)$ \\
\hline Dosen & 1 & 3,4 \\
Guru Honor & 1 & 3,4 \\
Ibu Rumah Tangga & 6 & 20,7 \\
Pegawai & 2 & 6,9 \\
Pelajar & 6 & 20,7 \\
Pensiunan PNS & 2 & 6,9 \\
PNS & 5 & 17,3 \\
Swasta & 4 & 13,8 \\
Tidak diketahui & 2 & 6,9 \\
\multicolumn{1}{c}{ Total } & 29 & 100,0 \\
\hline \multicolumn{2}{c}{}
\end{tabular}

Distribusi kasus kandidiasis vulvovaginalis berdasarkan riwayat keluhan pasien didapatkan keluhan terbanyak yaitu keputihan dan gatal sebanyak 10 kasus (34,5\%), keputihan, gatal, dan berbau sebanyak 7 kasus (24,1\%), serta yang datang dengan keluhan keputihan saja sebanyak 4 kasus (13,8\%).

Tabel 4. Distribusi Kasus Kandidiasis Vulvovaginalis Berdasarkan Riwayat Keluhan Pasien di RSUP Prof. Dr. R. D. Kandou Tahun 2013

\begin{tabular}{|c|c|c|}
\hline Riwayat Keluhan & $\begin{array}{c}\text { Jumlah } \\
\text { Kasus }\end{array}$ & $(\%)$ \\
\hline Keputihan & 4 & 13,8 \\
\hline Keputihan + Gatal & 10 & 34,5 \\
\hline $\begin{array}{l}\text { Keputihan + Gatal + } \\
\text { Bau }\end{array}$ & 7 & 24,2 \\
\hline $\begin{array}{l}\text { Keputihan + Gatal + } \\
\text { Bau + Nyeri }\end{array}$ & 3 & 10,3 \\
\hline $\begin{array}{l}\text { Keputihan + Gatal + } \\
\text { Kemerahan }\end{array}$ & 2 & 6,9 \\
\hline $\begin{array}{l}\text { Keputihan + Gatal + } \\
\text { Luka dikelamin }\end{array}$ & 3 & 10,3 \\
\hline Total & 29 & 100,0 \\
\hline
\end{tabular}

Distribusi kasus kandiasis vulvovaginal berdasarkan faktor predisposisi didapatkan penyebab terbanyak yaitu penggunaan douching dan kehamilan masing-masing sebanyak 4 kasus $(13,8 \%)$; 17 kasus (58,6\%) penyebab tidak diketahui.

Tabel 5. Distribusi Kasus Kandidiasis Vulvovaginalis Berdasarkan Faktor Predisposisi Pasien di RSUP Prof. Dr. R. D. Kandou Tahun 2013

\begin{tabular}{|c|c|c|}
\hline $\begin{array}{c}\text { Faktor } \\
\text { Predisposisi }\end{array}$ & $\begin{array}{c}\text { Jumlah } \\
\text { Kasus }\end{array}$ & $(\%)$ \\
\hline $\begin{array}{l}\text { Antibiotik } \\
\text { Dexamethason }\end{array}$ & 1 & 3,4 \\
\hline Dexamethason + & 1 & 3,4 \\
\hline $\begin{array}{l}\text { Douchin }+\mathrm{KB} \\
\text { Implant }\end{array}$ & & \\
\hline Diabetes & 1 & 3,4 \\
\hline Douching & 4 & 13,8 \\
\hline Hamil & 4 & 13,8 \\
\hline KB suntik & 1 & 3,4 \\
\hline Tidak diketahui & 17 & 58,8 \\
\hline Total & 29 & 100,0 \\
\hline
\end{tabular}


Distribusi kasus kandidiasis vulvovaginalis berdasarkan pemeriksaan Gram didapatkan hasil yang paling banyak ditemukan yaitu adanya spora + buddingcell + pseudohifa yaitu 18 kasus (62,1\%).

Tabel 6. Distribusi Kasus Kandidiasis Vulvovaginalis Berdasarkan Pemeriksaan Laboratorium Gram Pasien di RSUP Prof. Dr. R. D. Kandou Tahun 2013

\begin{tabular}{|c|c|c|}
\hline $\begin{array}{c}\text { Pemeriksaan } \\
\text { Laboratorium Gram }\end{array}$ & $\begin{array}{c}\text { Jumlah } \\
\text { Kasus }\end{array}$ & (\%) \\
\hline $\begin{array}{ll}\text { Buddingcell } & + \\
\text { Pseudohifa } & \end{array}$ & 1 & 3,4 \\
\hline Pseudohifa & 2 & 6,9 \\
\hline Spora + Buddingcell & 4 & 13,8 \\
\hline $\begin{array}{l}\text { Spora + Buddingcell + } \\
\text { Pseudohifa }\end{array}$ & 18 & 62,1 \\
\hline Spora + Pseudohifa & 4 & 13,8 \\
\hline Total & 29 & 100,0 \\
\hline
\end{tabular}

Distribusi kasus kandidiasis vulvovaginalis berdasarkan riwayat penyakit sebelumnya ditemukan pasien yang paling banyak yaitu pasien baru sebanyak 24 kasus (82,8\%) sedangkan pasien yang mengalami rekuren sebanyak 5 kasus $(17,2 \%)$.

Tabel 7. Distribusi Kasus Kandidiasis Vulvovaginalis Berdasarkan Riwayat Penyakit Sebelumnya di RSUP Prof. Dr. R. D. Kandou Tahun 2013

\begin{tabular}{ccc}
\hline $\begin{array}{c}\text { Riwayat Penyakit } \\
\text { Sebelumnya }\end{array}$ & $\begin{array}{c}\text { Jumlah } \\
\text { Kasus }\end{array}$ & $(\%)$ \\
\hline Pasien baru & 24 & 82,8 \\
Pasien rekuren & 5 & 17,2 \\
Total & 29 & 100,0 \\
\hline
\end{tabular}

Distribusi kasus kandidiasis vulvovaginalis berdasarkan terapi pasien didapatkan jumlah terbanyak yaitu terapi kombinasi sebanyak 14 kasus (48,3\%), kemudian terapi sistemik sebanyak 11 kasus $(38,0 \%)$, dan terakhir terapi topikal sebanyak 4 kasus (13,8\%).
Tabel 8. Distribusi Kasus Kandidiasis Vulvovaginalis Berdasarkan Terapi Pasien di RSUP Prof. Dr. R. D. Kandou Tahun 2013

\begin{tabular}{llcc}
\hline \multicolumn{1}{c}{ Terapi } & & $\begin{array}{c}\text { Jumlah } \\
\text { Kasus }\end{array}$ & (\%) \\
\hline Antifungi Sistemik & & 11 & 38,0 \\
Antifungi Topikal & & 4 & 13,8 \\
$\begin{array}{c}\text { Kombinasi : } \\
\text { Antifungi Sistemik }\end{array}$ & + & 6 & 20,7 \\
$\begin{array}{c}\text { Antifungi Topikal } \\
\text { Antifungi Sistemik }\end{array}$ & + & 3 & 10,3 \\
$\begin{array}{c}\text { Antibiotik Sistemik } \\
\text { Antifungi Sistemik }\end{array}$ & + & 2 & 6,9 \\
$\begin{array}{c}\text { Antibiotik Topikal } \\
\text { Antifungi Topikal }\end{array}$ & + & 1 & 3,4 \\
$\begin{array}{c}\text { Antibiotik Topikal } \\
\text { Antifungi Topikal }\end{array}$ & + & 2 & 6,9 \\
$\begin{array}{c}\text { Antibiotik Sistemik } \\
\text { Total }\end{array}$ & & 29 & 100,0 \\
\hline
\end{tabular}

\section{BAHASAN}

Dari data penelitian deskriptif retrospektif yang dilakukan selama periode Januari - Desember 2013 di Poliklinik Kulit dan Kelamin RSUP Prof. Dr. R. D. Kandou didapatkan jumlah kasus kandidiasis vulvovaginalis sebanyak 29 kasus $(0,70 \%)$ dari 47 kasus KVV yang ada di Devisi IMS dengan total keseluruhan ada 4.099 pasien yang berkunjung ke Poliklinik Kulit dan Kelamin (Tabel 1). Perbedaan pengambilan data ini disebabkan karena beberapa rekam medis pasien tidak ditemukan dan data di Devisi IMS tidak memenuhi variabel penelitian yang akan dilakukan. Dari 29 kasus ini, terdapat 13 kasus yang disertai dengan diagnosis penyakit lain seperti bakterial vaginosis, herpes genital, kondiloma akuminata, ulkus mole, dan suspek bartholinitis.

Pada tahun 1996-2001, penelitian yang dilakukan oleh Kandou R. T. dkk di Poliklinik Kulit dan Kelamin RSUP Prof. Dr. R. D. Kandou, didapatkan pasien dengan diagnosis kandidiasis vulvovaginalis sebanyak 245 (0,55\%) kasus (dikutip dalam Paseki EL). ${ }^{12}$ Pada periode Januari 2007 sampai Desember 2009 didapatkan kasus kandidiasis vulvovaginalis sebanyak 306 (1,6\%) kasus dari seluruh kasus yang ada di Divisi IMS Unit 
Rawat Jalan Poliklinik Kulit dan Kelamin RSUD Dr. Soetomo Surabaya. ${ }^{10}$

Pada penelitian retrospektif ini didapatkan prevalensi kandidiasis vulvovaginalis menurun bila dibandingkan dengan data pada tahun 2012 yaitu sebanyak 47 kasus (1,17\%) dari 4.023 pasien yang berkunjung di Poliklinik Kulit dan Kelamin RSUP Prof. Dr. R. D. Kandou. Hal ini bisa disebabkan karena data yang diambil untuk penelitian ini melalui rekam medik pasien tidak sesuai dengan data yang tercatat pada Devisi IMS. Selain itu, penderita mungkin saja berusaha melakukan pengobatan sendiri atau ditempat praktik dokter sehingga jumlah kasus KVV yang didapatkan dalam penelitian ini belum bisa memperlihatkan jumlah kasus yang ada dimasyarakat.

Dilihat dari distribusi kasus kandidiasis vulvovaginalis berdasarkan umur pasien selama tahun 2013 (Tabel 2), didapatkan kelompok umur penderita yang paling banyak yaitu umur 15-24 dan 25-44 tahun masing-masing terdapat 12 kasus (41,4\%). Hal ini sama dengan penelitian yang dilakukan oleh Karina dan Ervianti pada tahun 2007-2009, didapatkan mayoritas kelompok umur penderita KVV yaitu umur 25-44 tahun sebanyak 160 (52,3\%) kasus dan kelompok umur 15-24 tahun sebanyak 109 (35,6\%) kasus. $^{10}$

Banyaknya prevalensi kasus KVV yang ditemukan pada usia 15-24 tahun dan 25-44 tahun bisa disebabkan karena pada usia ini aktivitas seksual yang mulai meningkat, rendah hygiene kewanitaan, penggunaan kontrasepsi dan penyalahgunaan antibiotik yang dapat memacu pertumbuhan berlebih dari jamur Candida. Dari penelitian ini juga, didapatkan juga kelompok umur penderita KVV yang paling sedikit ditemukan yaitu umur 45-65 tahun sebanyak 4 kasus (13,8\%), dan lebih sedikit lagi ditemukan hanya 1 kasus (3,4\%) pada umur <5-14 tahun penderita. Pada usia postmenopause, berkaitan dengan adanya hormorn estrogen yang tinggi, sehingga jamur Candida mulai bertumbuh secara patogen pada mukosa vagina karena adanya kadar glikogen meningkat.
Pada penelitian ini, distribusi berdasarkan pekerjaan (Tabel 3) penderita KVV yang bekerja sebagai ibu rumah tangga dan pelajar (mahasiswa dan siswa) masing-masing terdapat 6 kasus (20,7\%) dan merupakan pekerjaan yang terbanyak. Profesi yang bekerja sebagai pekerja swasta terdapat 4 kasus (13,8\%). Hasil penelitian ini, sama dengan hasil penelitian yang dilakukan Karina dan Ervianti yang mendapatkan pekerjaan terbanyak ibu rumah tangga yaitu sebanyak 173 kasus (56,5\%), Kemudian diikuti pekerja swasta sebanyak $82(26,8 \%)$ kasus dan pelajar/ mahasiswa 31(10,1\%) kasus. Dalam penelitian yang dilakukan Karina dan Ervianti dikatakan bahwa hasil penelitian mereka sama dengan hasil penelitian yang dilakukan oleh Sandra pada tahun 20022006, dimana didapatkan pekerjaan terbanyak yaitu sebagai ibu rumah tangga sebanyak 45,29\% dan pekerja swasta $27,60 \%{ }^{10}$

Lebih banyak ditemukannya pekerjaan sebagai ibu rumah tangga dari status pasien KVV ini, bukan berarti penyakit ini banyak menyerang wanita yang berprofesi sebagai ibu rumah tangga, namun seperti yang diketahui bahwa KVV ini disebabkan oleh berbagai macam faktor. Selain itu, ibu rumah tangga juga memiliki waktu yang lebih luang untuk memeriksakan setiap keluhan yang mereka rasakan daripada mereka yang bekerja sebagai pekerja swasta atau PNS, tetapi mungkin saja wanita pekerja diluar rumah lebih memilih memeriksakan diri ke tempat praktik dokter secara langsung. Begitu halnya dengan siswa dan mahasiswa yang menderita KVV yang mungkin karena takut akan keluhan yang dialaminya bertambah lebih parah, sehingga datang untuk memeriksakan diri dengan sendirinya maupun dengan kerabat mereka. $^{12}$

Distribusi KVV berdasarkan keluhan yang dialami pasien (Tabel 4), keluhan terbanyak yang dijumpai dari status pasien yaitu adanya keputihan disertai gatal pada 10 kasus (34,5\%), selain itu keluhan adanya keputihan, gatal, dan berbau didapatkan ada 7 kasus (24,1\%). Dari hasil 
penelitian ini, sesuai dengan teori tentang manifestasi klinis yang khas dari KVV. Keluhan subjektif yang dirasakan penderita KVV memang dapat bervariasi dari ringan hingga berat, namun adanya keputihan/duh tubuh dan rasa gatal pada vagina merupakan keluhan khas dari penderita KVV. Walaupun duh tubuh yang dialami setiap pasien berbeda namun seringkali disertai berbagai macam keluhan lainnya seperti adanya bau asam, nyeri, disuria, rasa terbakar, hingga tampak kemerahan, sehingga hal ini tidak menutup kemungkinan adanya keluhan duh tubuh tanpa adanya keluhan lain yang menyertai. ${ }^{2,12-16}$

Distribusi KVV berdasarkan faktor predisposisi pasien (Tabel 5), didapatkan bahwa penggunaan douching (antiseptik pembersih kewanitaan) dan kehamilan masing-masing pada 4 kasus (13,8\%) sebagai faktor predisposisi tunggal yang dapat menyebabkan KVV dan merupakan penyebab terbanyak. Tetapi terdapat 17 kasus (58,6\%) pada pasien tidak diketahui faktor predisposisi yang menyebabkan KVV. Hal ini disebabkan karena sebagian besar faktor predisposisi tidak tertulis pada rekam medik saat anamnesis.

Menurut kepustakaan, wanita yang mengalami KVV dikaitkan dengan mulftifaktorial penyebab. Selain penggunaan antiseptik sebagai pembersih kewanitaan, adanya kehamilan, namun faktor resiko seperti penggunaan antibiotik spektrum luas, kontrasepsi hormonal, menderita diabetes, dan penggunaan pakaian dalam yang ketat menjadi salah satu penyebab KVV. Penderita yang mengalami KVV, ada yang memiliki faktor predisposisi yang lebih dari satu. Penggunaan antiseptik pembersih kewanitaan (douching) dan antibiotik dapat mengurangi perlindungan flora normal pada vagina sehingga dapat menjadi media pertumbuhan Candida. ${ }^{8,9}$ Prevalensi KVV pada wanita hamil (70\%) dengan terinfeksi Candida albicans meningkat pada trimester ketiga kehamilan (59,5\%) dikarenakan terjadi peningkatan jumlah glikogen dan hormon estrogen yang menjadi media pertumbuhan terbaik bagi
Candida. ${ }^{9,12,18}$

Distribusi kasus KVV berdasarkan pemeriksaan laboratorium (Tabel 6), dapat dilihat dari hasil pemeriksaan gram yang dilakukan, didapatkan adanya spora, budding cell, pseudohifa merupakan hasil pemeriksaan terbanyak yang ditemukan yaitu 18 kasus (62,1\%). Pemeriksaan laboratorium merupakan salah satu jenis pemeriksaan penunjang suatu diagnosis penyakit. Melalui pemeriksaan gram, lebih baik karena lebih mudah, infeksi KVV dapat ditemukan adanya pseudohifa, hifa panjang bersepta, dan spora positif. ${ }^{10,17}$ Gambaran pseudohifa dan blastospora hampir selalu ada pada pemeriksaan langsung semua Candida sp. Gambaran budding cell hanya dapat ditemukan pada spesies Candida albicans saja. Selain pemeriksaan gram, dapat juga dilakukan pemeriksaan lainnya seperti pemeriksaan laboratorium sediaan basah dengan normal salin atau $\mathrm{KOH} 10-20 \%$ yang berguna untuk mengidentifikasi blastospora, budding cell, pseudohifa, dan hifa serta berguna juga untuk menyingkirkan adanya trikhomoniasis dan infeksi bakterial vaginosis (tampak clue cell). ${ }^{19}$

Selain itu, dalam hasil penelitian ini dapat diketahui pula distribusi KVV berdasarkan riwayat penyakit sebelumnya (Tabel 7), terdapat 24 kasus (82,8\%) penderita yang baru pertama kali terserang infeksi KVV dan 5 kasus (17,2\%) datang sebagai pasien lama yang mengalami infeksi berulang atau rekuren. Kandidiasis vulvovaginal rekuren/KVVR terjadi bila infeksi mengalami kekambuhan 4 atau lebih dalam 1 tahun. KVVR didapatkan 58\% pada kasus. ${ }^{5,9,12,20}$ Terjadinya kasus KVVR bisa saja disebabkan karena mungkin kurang adekuatnya penanganan yang diberikan kepada pasien, adanya penyakit sindrom metabolik seperti DM yang dapat menyebabkan insidensnya sulit diturunkan, terjadi penekanan sistem imun, serta mungkin saja pasien yang tidak minum obat atau kontrol secara rutin sesuai anjuran dokter bahkan tidak menutup kemungkinan untuk sulit menghindari faktor pencetus terjadinya KVV. 
Jenis terapi yang diberikan kepada pasien (Tabel 8), terapi terbanyak yang diberikan yaitu terapi kombinasi ada 14 kasus (48,3\%), diikuti terapi sistemik ada 11 kasus (37,9\%), terapi topikal ada 4 kasus (13,8\%). Pengobatan KVV dapat diberikan secara tunggal maupun kombinasi. Terapi topikal merupakan jenis terapi yang diberikan dengan gejala yang ringan, dan terapi sistemik diberikan kepada pasien dengan gejala yang berat. ${ }^{10}$ Mengobati penyakit penyerta lainnya juga tidak kalah pentingnya dalam sebuah penanganan KVV.

\section{SIMPULAN}

Dari hasil penelitian deskriptif retrospekstif di Poliklinik Kulit dan Kelamin RSUP Prof. Dr. R. D. Kandou periode Januari - Desember 2013, dapat ditarik kesimpulan bahwa kasus kandidiasis vulvovaginal didapatkan sebanyak 29 kasus (0,70\%) dimana 24 kasus merupakan pasien yang baru pertama kali terinfeksi. Lebih banyak ditemukan pada usia 15-24 dan 25-44 tahun, berprofesi sebagai IRT dan pelajar, serta pada pengguna douching dan kehamilan. Keluhan tersering yaitu keputihan dan gatal. Pemeriksaan gram banyak ditemukan spora, pseudohifa dan budding cell serta terapi kombinasi yang paling banyak digunakan.

\section{SARAN}

Perlu dilakukan penelitian lebih lanjut mengenai kandidiasis vulvovaginalis, karena data yang ditemukan di Indonesia masih sedikit yang melakukan penelitian ini dan secara khusus di Kota Manado.

Perlu dilakukan pengisian dan penyimpanan status pasien dengan lengkap, baik, dan jelas agar mempermudah bagi peneliti untuk melakukan penelitian selanjutnya

\section{DAFTAR PUSTAKA}

1. Toua V, Djaouda M, Gake B, Menye DE, Christie EA, Tambe E, et al. Prevalence of Vulvovaginal Candidiasis amongst Pregnant Women in Maroua (Cameroon) and
The Sensitivity of Candidia albicans to Extracts of Six Locally used Antifungal Plants. IRJM. 2013;4(3):89-97.

2. Bhagat BP, Desai PB. Vulvovaginal Candidiasis: Isolation and Identification of Candida from Reproductive Age Group Women. Res J Recent Sci. 2014;3:30.

3. Pudjiati SR, Soedarmadi. Kandidiosis Genitalis. Infeksi Menular Seksual (4th ed). Jakarta: FKUI, 2009; p. 171.

4. Krapf JM. Vulvovaginitis Clinical Presentation. 2015. [diakses 18 September 2015]. Diunduh dari: http://emedicine.medscape.com/articl e/2188931-overview\#a7

5. Nelson M, Wanjiru W, Margaret MW. Prevalence of Vaginal Candidiasis and Determination of the Occurrence of Candida species in Pregnant Woment Attending the Antenatal Clinic of Thika District Hospital, Kenya. OJMM. 2013;3:264-8.

6. Faraji R, Rahimi MA, Rezvanmadani F, Hashemi M. Prevalence of Vaginal Candidiasis Infection in Diabetic Women. AJMR. 2012;6(11):2773-8.

7. Bahupati OW. Hubungan Pengetahuan Kesehatan Alat Reproduksi Dengan Kejadian Kandidiasis Vulvovaginalis Pada Penderita Kandidiasis Vulvovaginalis. Surakarta: Fakultas Kedokteran Universitas Muhammadiyah; 2015.

8. Alli JAO, Okonko IO, Odu NN, Kolade AF, Nwanze JC. Detection and Prevalence of Candida Isolates Among Patients in Ibadan, Southwestern Nigeria. JMBR. 2011;1(3):176-84.

9. Tiyyagura S, Taranikanti M, Ala S, Mathur DR. Prevalance of Vulvovaginal Candidiasis in Women of Reproductive Age Group. IJBR. 2013;4(1):42-4.

10.Karina D, Ervianti E. Kandidiasis Vulvovaginalis di Divisi Infeksi Menular Seksual Unit Rawat Jalan Kesehatan Kulit dan Kelamin RSUD Dr. Soetomo Surabaya Periode 20072009. 2011;23:p.182-4.

11.Daili SF. Infeksi Menular Seksual. Ilmu Kebidanan (4th ed). Jakarta: P.T. Bina Pustaka Sarwono Prawirohardjo; 
2014.p.921-23

12.Hakim L. Epidemiologi Infeksi Menular Seksual. Ilmu Penyakit Kulit dan Kelamin (6th ed). Jakarta: FKUI, 2010; p. 129-38.

13.Essel E, Etego LA, Quaye SL. A Case Study of the Incidence and Risk Factor of Vaginal Candidiasis in a Girl's Senior High School in Bolgatanga, Ghana. IJHSR. 2014;4:212-5.

14.Al-Ahmadey ZZ, Mohamed SA. Vulvovaginal Candidiasis: Agents and its virulence factors. NetJournals. 2014;2(3):28-32

15.Sobel JD. Vulvovaginalis Candidiasis. In: Holmes KK, Sparling PF, Stamm WE, Piot P, Wasserheit JN, Corey L, et al, editors. Sexually Transmitted Diseases (2nd ed). New York: McGraw-Hill, 2008; p. 823-35.

16.Murtiastutik D. Kandidiasis Vulvovaginalis. Buku Ajar Infeksi Menular Seksual. Surabaya:FK Unair, 2008; p. 56-63.

17.Paseki EL. Profil Duh Tubuh Vagina di
Poliklinik Kulit dan Kelamin RSU Prof. Dr. R. D. Kandou Manado Januari 2006 - Desember 2007. Manado: Fakultas Kedokteran Universitas Sam Ratulangi; 2008.

18. Oyewole OA, Okoliegbe IN, Alkhalil S, Isah P. Prevalence of Vaginal Candidiasis among Pregnant Women Attending Federal University of Technology, Minna, Nigeria, Bosso Clinic. RJPBCS. 2013;4(1):113-20.

19.Ervianti E, Sawitri, Murtiastutik D, Agusni RI. Pola Pergeseran Candida sp. Penyebab Kandidiasis Vulvovagonalis dan Kandidiasis Vulvovaginalis Rekuren. Berkala Ilmu Kesehatan Kulit dan Kelamin. 2011;23(3):189-99.

20.Apalata T, Longo-Mbeza B, Sturm AW, Carr WH, Moodley P. Factor Associated with Symptomatic Vulvovaginal Candidiasis: A Study Among Women Attending A Primary Healthcare Clinic In Kwazulu-Natal, South Africa. AMHSC. 2014;4:410-5. 